\title{
Unraveling the Nexus of Science Technology Input and Economic Growth through Research Development (RD) Indicators in Asia-pacific Region: A Panel Data and Causality Analysis
}

\author{
Emmanuel A. Onsay*1,2 \\ ${ }^{1}$ School of Economics, De La Salle \\ University Manila, Philippines \\ ${ }^{2}$ College of Business and Management \\ Partido Institute of Economics, Partido State \\ University Goa, Camarines Sur, Philippines \\ Correspondence \\ *Corresponding Author. \\ Email: emmanuel.onsay@parsu.edu.ph
}

\begin{abstract}
This paper unravels the critical aspect of science and technology through research and development indicators as sources, drivers, and predictors of economic growth from the perspective of two developing countries, namely: Philippines and Thailand (ASEAN), and two developed economies, namely: Japan and Australia (ASEAN-X) in Asia-Pacific Region. The data set ranges from 1980 to 2019 and is collected from World Development Indicators of the World Bank, Institute for Statistics of United Nations Educational, Scientific and Cultural Organization (UNESCO), and World Intellectual Property Organization (WIPO). Research and Development (RD) is a tool for generating new knowledge and serves as input for technological advancement. In the long run, it has been proven that technology can sustain permanent economic development in the economy. In developed economies, the nexus between the aforementioned variables is robust and significant. Thus, the RD indicators can be used as a predictor of economic growth. However, in developing economies, the nexus of variables involved is negligible and insignificant. Hence, the RD indicators cannot be effectively utilized as a predictor of economic growth. Furthermore, the study combined the two sets of panel data and a relevant conclusion was drawn. A country-panel regression and causality analysis were performed based on the empirics of macroeconomics.
\end{abstract}

\section{KEYWORDS:}

Nexus, Science and Technology, Research and Development Indicators, Economic Growth, Panel Regression, Asia-Pacific Region

\section{1 | INTRODUCTION}

Research claims that investment in itself yields higher returns exceeding the cost of investment. (UNESCO UIS, 2020). While the amount and proportion vary, research development could be considered as a regressor of economic growth. With the foregoing, the returns formed part of the gross domestic product derived by a country for a given span of period, and its spillover effect the gross national income generated by a country for a given duration of time. Thus, to clutch this potential and gauge opportunities in the long run, the governments, various organizations, and policymakers need accurate, relevant, and error-free data for rational and cross-functional decision-making through cautious macro-econometric analysis. The nexus between science and technology input through research and development indicators, and economic growth has rooted in the school of thoughts of Neo-classical 
economists which focus on the economics of growth. The classified technical progress becomes a contributory element for economic growth when neutral technical progress is emphasized on hypothetical assumptions. The Solow Residual asserted such an approach by which the influence and involvement of the degree of technical progress on the growth of the economy could be accounted for (Solow, 1957). Moreover, a tight relationship between technological input and economic growth has been claimed by Gary, et.al., (1992) when the portion of domestic Science and Technology capitalized funds on the Gross Domestic Product (GDP) among Organization for Economic Co-operation and Development (OECD) member countries have been compared. In 1999, Romer affirmed that the marginal effect of the diminishing law of capital can be circumvented and the steadiness of economic growth could be maintained through endogenized technical progress. Thus, an experiential study concerning science and technology input through research and development indicators that may reveal its nexus to economic growth is highly necessary. There is a long-term implication of varying research and development inputs on the economic growth according to Guellec, et. al. (2001). Meanwhile, Licheng (2011) concluded that science and technology input has an existing link to economic growth after evaluating the three (3) foremost economic regions in the coastal areas of China. The study pursued to answer the following questions: how robust/significant is the nexus/relationship of science and technology input as represented by research and development indicators, and economic growth?; Is there a difference/disparity between science technology input as represented by research and development indicators, and economic growth of four selected countries in the Asia-Pacific Region?; and does science technology input through research development indicators foster/drive long-run economic growth between developing countries (Philippines and Thailand), and developed countries (Japan and Australia)? Furthermore, this study aims to examine the link between research development and economic growth in Asia-Pacific Region, namely: Philippines, Thailand, Japan, and Australia. Specifically, it desires to: compare the science technology input through research and development parameters, and economic growth between developing countries, and developed countries; analyze the relationship/link/nexus of science technology input through research and development parameters, and economic growth of developing countries, and developed countries; examine the difference/disparity of science technology input through research and development parameters and economic growth of four selected countries in the Asia-Pacific Region, and evaluate science technology input through research and development parameters as a predictor of economic growth of four selected countries in the Asia-Pacific Region. The four countries were objectively selected based on their economic growth status and macroeconomic indicators. They are statistically comparable across various observations. Australia and Japan are both developed countries while the Philippines and Thailand are both developing. This study also intends to compare how ST inputs through RD indicators predict the economic growth of developed and developing countries. Thus, it is vital to test the two clusters of countries for meaningful results. This paper intends to provide strong evidence whether the null hypothesis could be rejected or the evidence fail to reject the null hypothesis. The null hypothesis proposes that there are no relationships or differences between the characteristics of the data observed. Such that there is no significant relationship between science technology input, and economic growth variables and there is no significant difference between the means of science technology input and economic growth variables. The research development indicators cannot be used effectively as predictors or drivers of economic growth. With the foregoing, this study is necessary to validate economic theories or refute economic assertions.

\section{2 | METHODOLOGY}

\section{1 | Sources of Data}

The secondary data were mined from World Bank, UNESCO IS, and the WIPO data repository. The data were downloaded through excel files, and CCV, and were filtered or screened objectively to select the variables that would be expedient for the study. The researcher utilized MS Excel, R, SSR, and Stata for data manipulation and analyses. This study is limited to the four countries in Asia-Pacific that are members of the ASEAN and ASEAN-X. These are objectively chosen because the researcher wants to compare and evaluate the influence of research and development indicators on the economic growth of these countries who are divided into two-panel data set, namely: developed and developing economies. No comprehensive study has been conducted yet in the Philippines regarding the analysis of the nexus of RD indicators and economic growth. Besides, no study has been conducted yet in Partido State University focusing on Macroeconomic perspectives. Moreover, panel regression and causality analysis were used.

The researcher used the Hausman test to decide between fixed or random effects. This tests whether the unique errors (ui) are correlated with the regressors, the null hypothesis is they are not (Green, 2008). The researcher ran a fixed and random effects model, saved the estimates, and then performed the test. The Hausman test shows that Prob $>$ chi2 is greater than 0.05 . If 
the result is $<0.05$ (significant), fixed effects should be used. Thus, the researcher employed random effects rather than fixed effects. Moreover, the results of the Breusch-Pagen test for heteroscedasticity, with a test statistic of 18.97. When compared to a Chi-Squared distribution with one degree of freedom, the resulting $\mathrm{p}$ value falls well below the standard .05 level. Thus, this is clear evidence to reject the null hypothesis of homoscedasticity and accept the alternative hypothesis that we do have heteroscedasticity in the residual of this regression model. The Variation Inflation Factors (VIF) is used as the basis to determine whether multicollinearity is a problem. Wooldridge (2013) noted that multicollinearity is a problem when the VIF is higher than 10. The VIF is not higher than 1, thus, in this study, multicollinearity is not a problem. Test of Autocorrelation was performed. The result shows that the null hypothesis of no serial correlation is strongly rejected (p-Value 0.0000). This means an alternative hypothesis was accepted where there is a serial correlation in the model. With a positive serial correlation, the OLS estimates of the standard errors will be smaller than the true standard errors. This will lead to the inference that predictions of the parameters are more reliable than they are. Therefore, it is a must to remove the serial correlation in the model.

\section{2 | Econometric Model}

The researcher employed Panel Regression and Causality Analysis. It was utilized to reveal the link between science technology input and the economic growth of the four countries involved. The econometric model below was used for panel regression analysis. Moreover, Causal analysis is an econometric design that is concerned with establishing cause and effect between given variables.

$$
d=\beta 0+\beta 1 i+\sum_{m=1}^{m} \delta_{m} r_{m}
$$

where $\mathrm{d}=$ Economic Growth (dependent variable) measured through Growth Rates of Gross Domestic Product and Gross National Income per Capita, $i$ represents Research and Development indicators (independent variables) and $r_{m}$ captures all other control variables

There are two based models estimated in this study, these are the following:

Model 1

GRGDPCit $=\beta 0+\alpha i+1$ STI-RND-Expit $+\beta 2$ GR_STI-RND-NumResit $+\beta 3$ GR_STI-RND-SciTechJoArtit $+\beta 4$ GR_STI-RND-NumTech $i t+\beta 5$ GR_STI-RND-PatAppit + $\beta 6$ GR_STI-RND-TradMAppit $+\varepsilon i t$

Model 2

GRGNIPCit $=\beta 0+\alpha i+\beta 1$ STI-RND-Expit $+\beta 2$ GR_STI-RND-NumResit $+\beta 3$ GR_STI-RND-SciTechJoArtit $+\beta 4$ GR_STI-RND-NumTechit $+\beta 5$ GR_STI-RND-PatApp $i t+\beta 6$ GR_STI-RND-TradMAppit $+\varepsilon i t$

Where:

$i=$ country; $t=$ year

GRGDPCit $=$ the rate of growth of GDP for country $i$ at year $t$;

GRGNIPCC $i t=$ the rate of growth of GNI for country $i$ at year $t$;

STI-RND-Expit $=$ the Percentage of GDP of Research and development expenditure for country $i$ at year $t$

GR_STI-RND-NumResit $=$ the Growth Rate of Researchers in RD (per million people) for country $i$ at year $t$

GR_STI-RND-SciTechJoArtit = the Growth Rate of Scientific and technical journal articles for country $i$ at year $t$

GR_STI-RND-NumTechit = Growth Rate of Technicians in RD (per million people) for country $i$ at year $t$ GR_STI-RND-

PatAppit $=$ Growth Rate of Patent Approved for country $i$ at yeart

GR_STI-RND-TradMAppit $=$ Growth Rate of Trademark Approved for country $i$ at year $t$

$\beta=$ is the coefficient for research and development indicators; and

$\varepsilon i t=$ is the error term 
TABLE 1 List of Variables

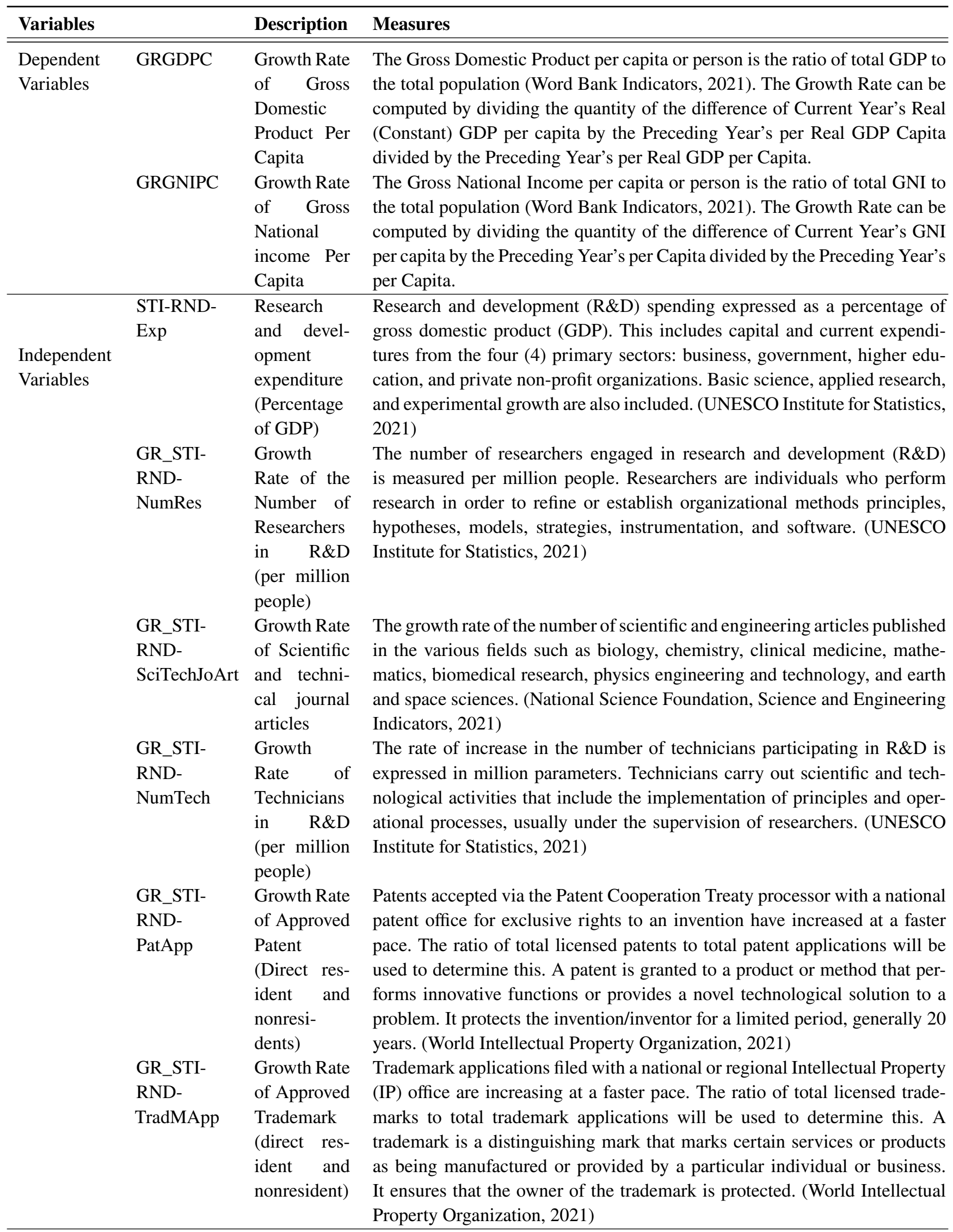




\section{3 | RESULTS}

\subsection{Science Technology Input through Research and Development Indicators, and Economic Growth}

\subsection{1 | The Economic Growth}

The Real Gross Domestic Product was used in the computation. The GDP Per Capita is the ratio of the Real GDP to the entire population of respective countries. The researcher preferred Real GDP because it is adjusted with inflation and reflects the factual values. To arrive at a reliable comparison, the constant GDP per capita was utilized in determining the growth rates. Such proposition aligns with the assertion of Kravis, et. al (1978) that the real GDP is best used as an indicator of economic growth. Figure 1 shows the Growth Rates of GDP Per Capita of Four countries in Asia-Pacific. Two of which, Australia and Japan are developed countries while the other two, the Philippines and Thailand are developing or emerging economies. The growth rates significantly differ. Japan and Australia which have the highest real GDP and GDP Per capita reflect lower plots of growth rates due to the base effects. These two countries already achieved higher bases; thus, changes are immaterial. From 1960 to 1999 , Japan has the highest GDP per capita while from 2,000 onwards, Australia reflects higher GDP per capita among the countries observed. From 1960 to 1982, the Philippines has higher GDP per capita as compared with Thailand. But from 1983 onwards, Thailand surpassed the Philippines. Thus, the country which has the lowest GDP per capita among the observations in the Philippines. The graph also shows that the Philippines suffered a recession from 1983 to 1985 during Marcos Regime. It parallels the findings of Sicat (1984) and Hill (1986). Such economic collapse is attributed to the impairment of confidence and credit ratings of the country from international financial institutions. With the foregoing, the Philippine government encountered borrowing problems since they cannot generate new capital to compensate for the increasing budget deficit, including the settlement of interest associated with the debt. In 1996-1997, Thailand suffered from Asian Financial Crisis when the country unpegged their currency, the Thai baht from the US Currency, dollar, thus brought currency impairment and immense breakouts of capital.

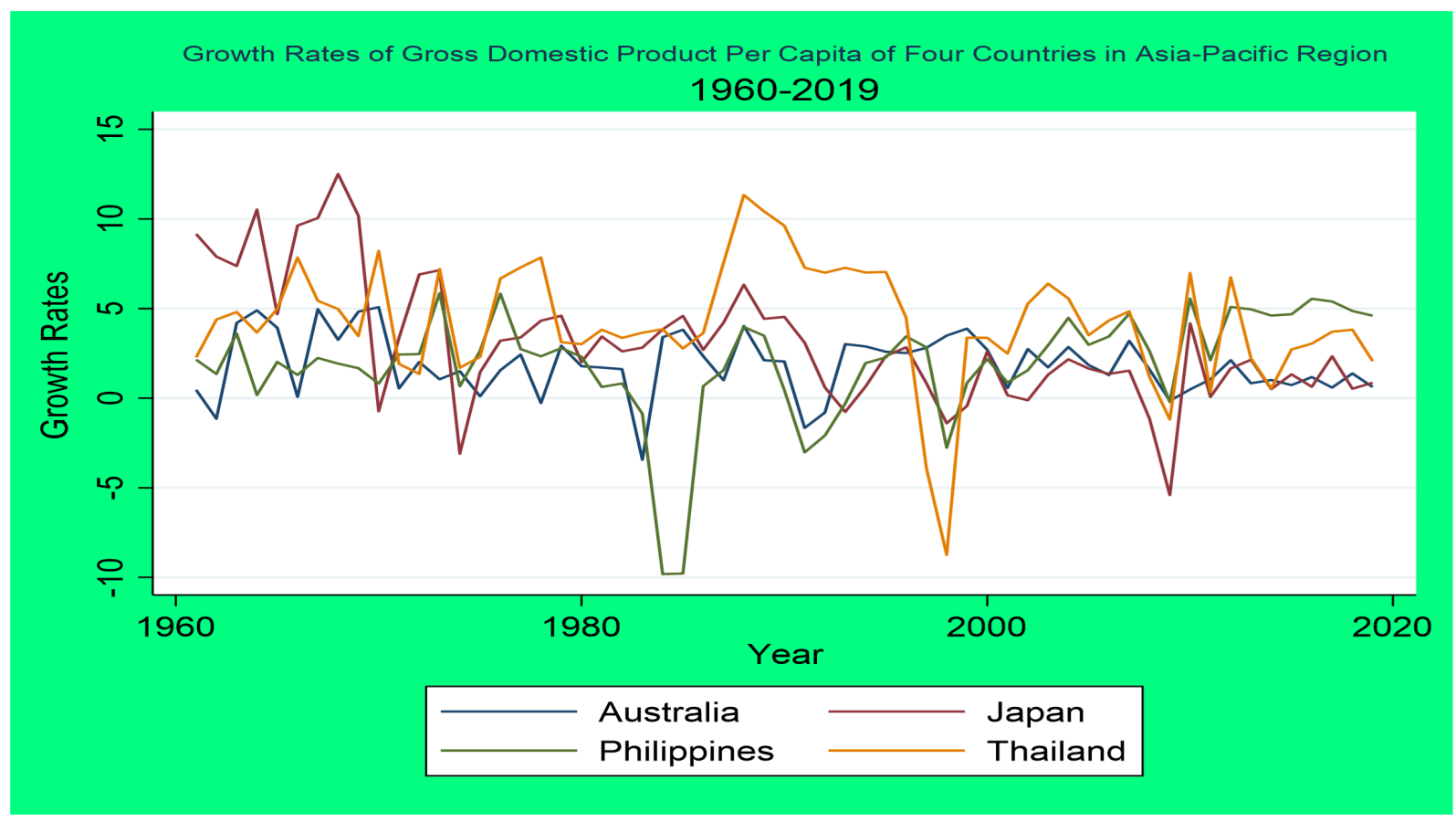

FIGURE 1 Rates of Growth of GDP Per Capita of Four Countries in Asia-Pacific Region

Japan has the greatest population followed by the Philippines, while Australia has the least population. The Philippines and Thailand are almost at par as to economic performance, but it is undeniable that the latter performs well in the recent decade. This indicator is the second variable utilized in determining the economic growth of the countries involved. Figure 2 shows the gross national income of selected countries in Asia-Pacific, converted to the currency of the USA in dollars through the World 
Bank Atlas method. The GNI is the entirety of value added by all resident producers plus any product taxes (fewer subsidies) not included in the valuation of output plus net receipts of primary income (compensation of employees and property income) from abroad (World Bank, 2021). GNI equals GDP plus income earned by residents from outside the country minus income earned in the nation by residents from other nations outside the country. Thus, the GNI is higher compared with the GDP. From 1987 to 1999, Japan's GNI is higher compared with Australia but from the year 2000 onwards, Australia's GNI is higher among the observed countries. The Philippines and Thailand have the almost same growth and economic performance. But the latter performed better in recent years. In 1988, Thailand experienced an economic surge and depicted by the graph. According to Niksch (1989), the bloom in the economy is brought by the surge in exports and expansion of the industrial sector. Concerning the growth rates of GNI in Japan and Australia, the two countries have an average to lower GNI growth rates because of reaching the optimal level of GNI. The Philippines has significant declines in its GNI per capita growth rates, although the GNI is increasing, the population is rising. Thus, it compensates for the corresponding increase by a greater denominator of economic growth. Moreover, the Thailand and Philippines have similar GNI growth rate trends as developing countries and are affected by Asian Financial Crisis. The GNI per capita growth rate is the second utilized variable of economic growth.

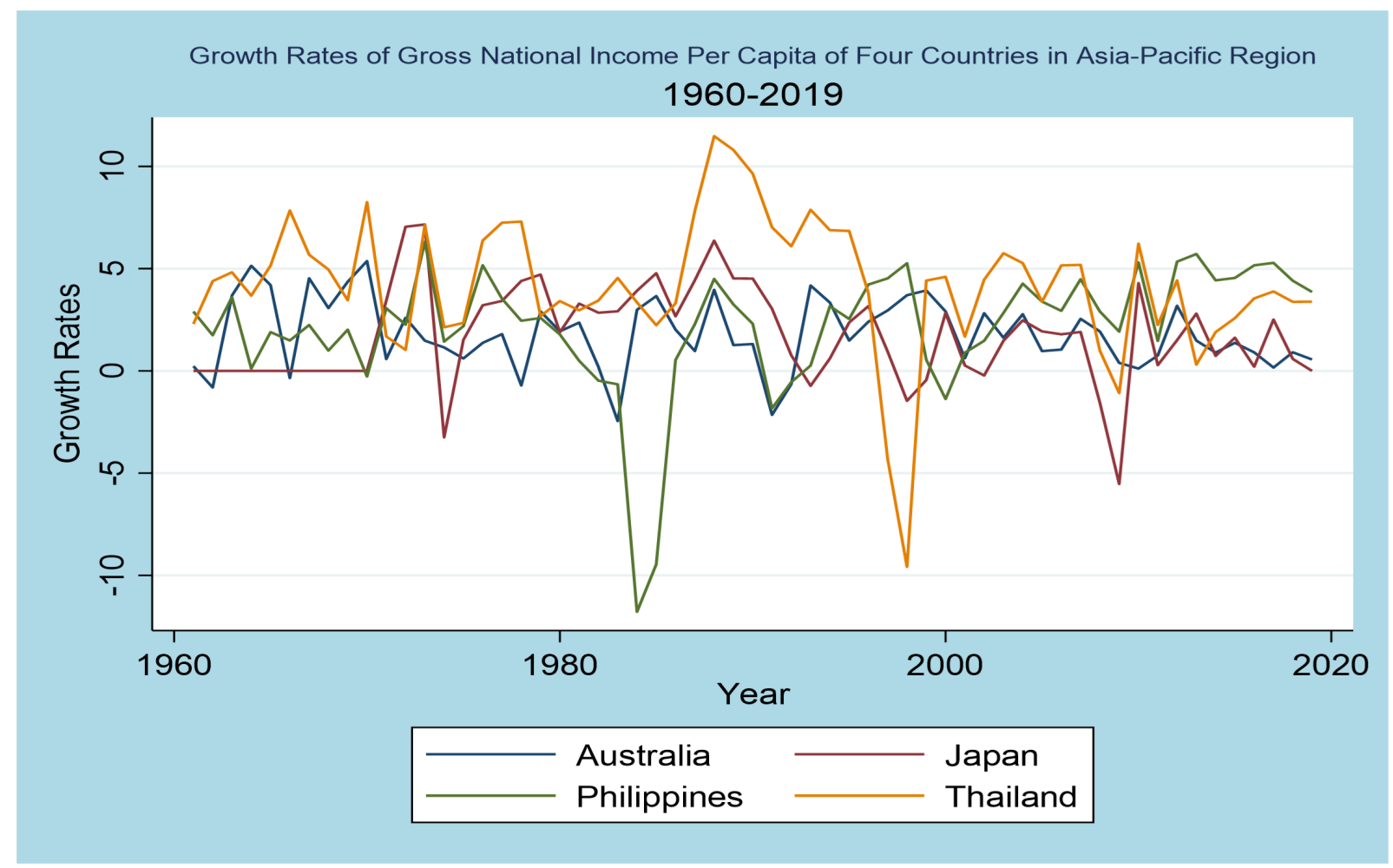

FIGURE 2 Rates of Growth of GNI Per Capita of four Countries in Asia-Pacific

\subsection{2 | Science and Technology Input through Research and Development Indicators}

According to UNESCO Institute for Statistics (2021), the Research and Development (RD) expenditure is a science and technology input, and the Research and Development Indicator is measured as the percentage of GDP. This consists of capital and current expenses from the four primary sectors, namely: Business enterprise, Government, Higher education, and Private nonprofit. Basic science applied research, and experimental advancement is all included. Based on Figure 3, Japan has the highest expenditure in research and development as a percentage of GDP.

Japan is the fourth country in the world that has the greatest expenditure in research and development, amounting to 172.614 as expressed in billions of US dollars, purchase power parity. Based on Solow Growth Model, technology can sustain permanent economic development in the long run. To create technological advancement, the country must invest in research and development to generate new ideas and knowledge. The investment of Japan as to research and development is constantly rising. 


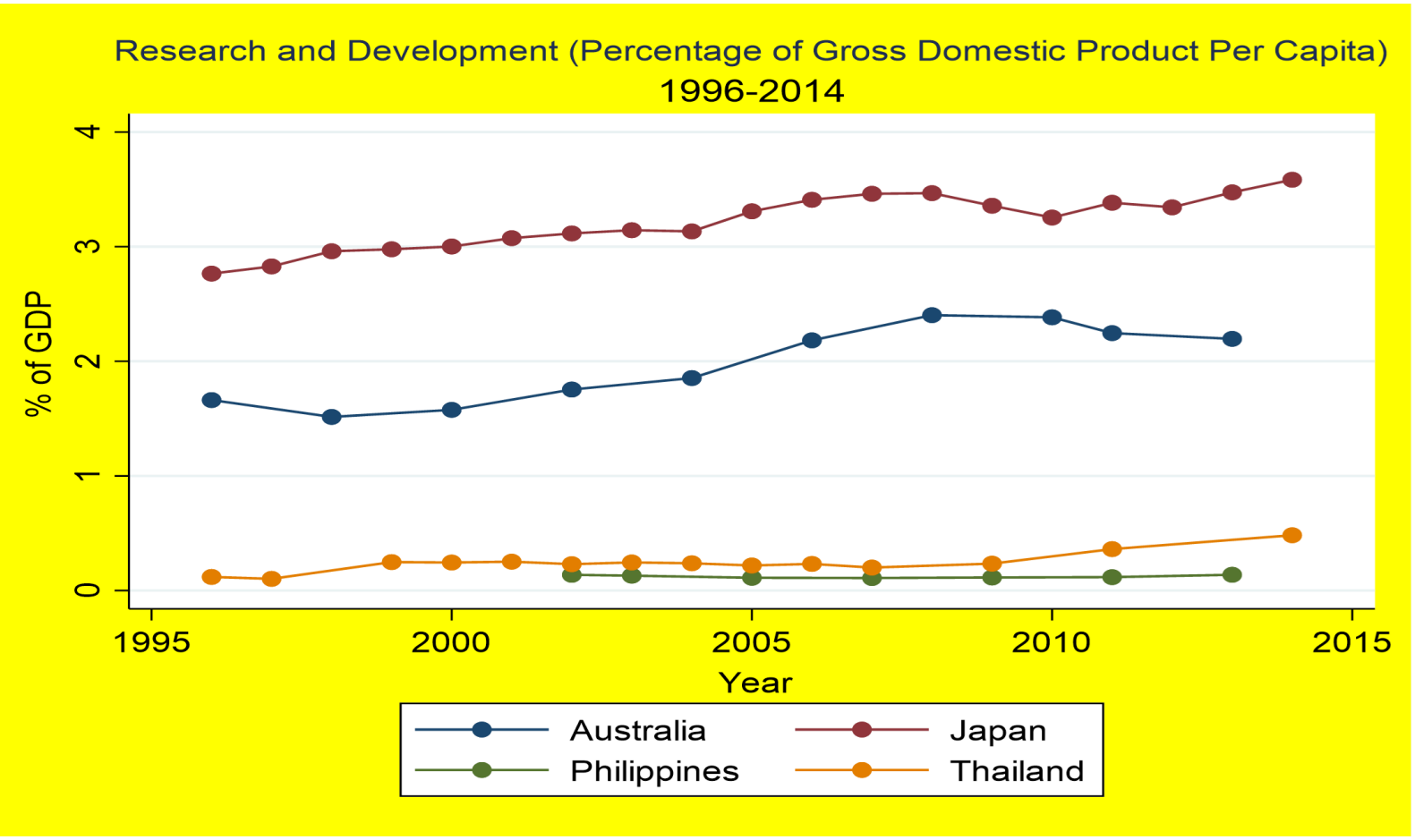

FIGURE 3 Expenditure on Research and Development as Percentage of Gross Domestic Product Per Capita

Thus, they are highly industrialized, and technological development occurred in recent scores. The country aims to become a technology-oriented and advanced science nation (MEXT, 2021). Australia spent an average of 1.5\% of GDP since 1996. In 2010, it ranked fifteenth among countries that have the highest research expenditure. However, in 2020, the country's expenditure on RD has dropped to $1.79 \%$ of GDP, far lower than the OECD average of $2.37 \%$, and extremely below the world RD leaders such as Israel with 4.94\% and South Korea with 4.53\% based on Sydney's Annual (2020), OECD and Worldbank (2020). The Philippines and Thailand are developing countries. Their average RD investment is $0.16 \%$ and $0.33 \%$ of GDP, respectively. Moreover, the two countries have availability of data from 1996 to 2001. Thailand's RD expenditure and manpower in 2018 increased by $17.5 \%$ from the previous year (NXPO, 2020). Moreover, RD in the Philippines is not fully utilized. The recognition of RD as a driver of economic growth is not truly recognized. Shown in Figure 4 is the number of technicians involved in RD, expressed in per million people parameter. This was calculated using data from the UNESCO Institute for Statistics (2021). Technicians carry out scientific and technological activities that include the implementation of principles and operational processes, usually under the supervision of researchers. The country which has the highest number of Technicians is Australia and is being followed by Japan. Since the Philippines and Thailand are developing and have lower expenditure in RD, technicians in these countries are lesser. Furthermore, statistics concerning these developing countries as to the number of technicians was incomplete. However, available data attest that technicians from such countries are tremendously lower compared with Japan and Australia.

According to World Intellectual Property Organization (2021), a patent is granted to a product or method that performs innovative functions or provides a novel technological answer or result to a problem. It gives the invention/inventor protection for a set amount of time, usually 20 years. The data in Figure 5 refers to the total number of patents approved/registered for exclusive rights to an invention through the Patent Cooperation Treaty processor with a national patent office. Japan has the highest number of approved or registered patents among the four countries and ranked third as the country which has the highest number of patent grants in 2018 per WIPO. Moreover, Australia ranked eleventh and is utilizing patents to improve its industry (IP Australia, 2021). It concurs that patents can drive economic growth when properly utilized at the country level (Raghupathi, 2017). From 1980 to 2016, Philippines patents are much greater compared to Thailand. Recently, the number of patent grants in Thailand exceeds the Philippines. The two countries are at par and perform similarly concerning patent utilization. It is also evident that developing countries have a far lower number of registered patents compared with developed economies.

In Figure 6, it is apparent that Japan has the highest number of registered trademarks among the countries involved, and ranked sixth according to Indexmundi (2018). A trademark is a distinguishing mark that recognizes certain services or products as being 


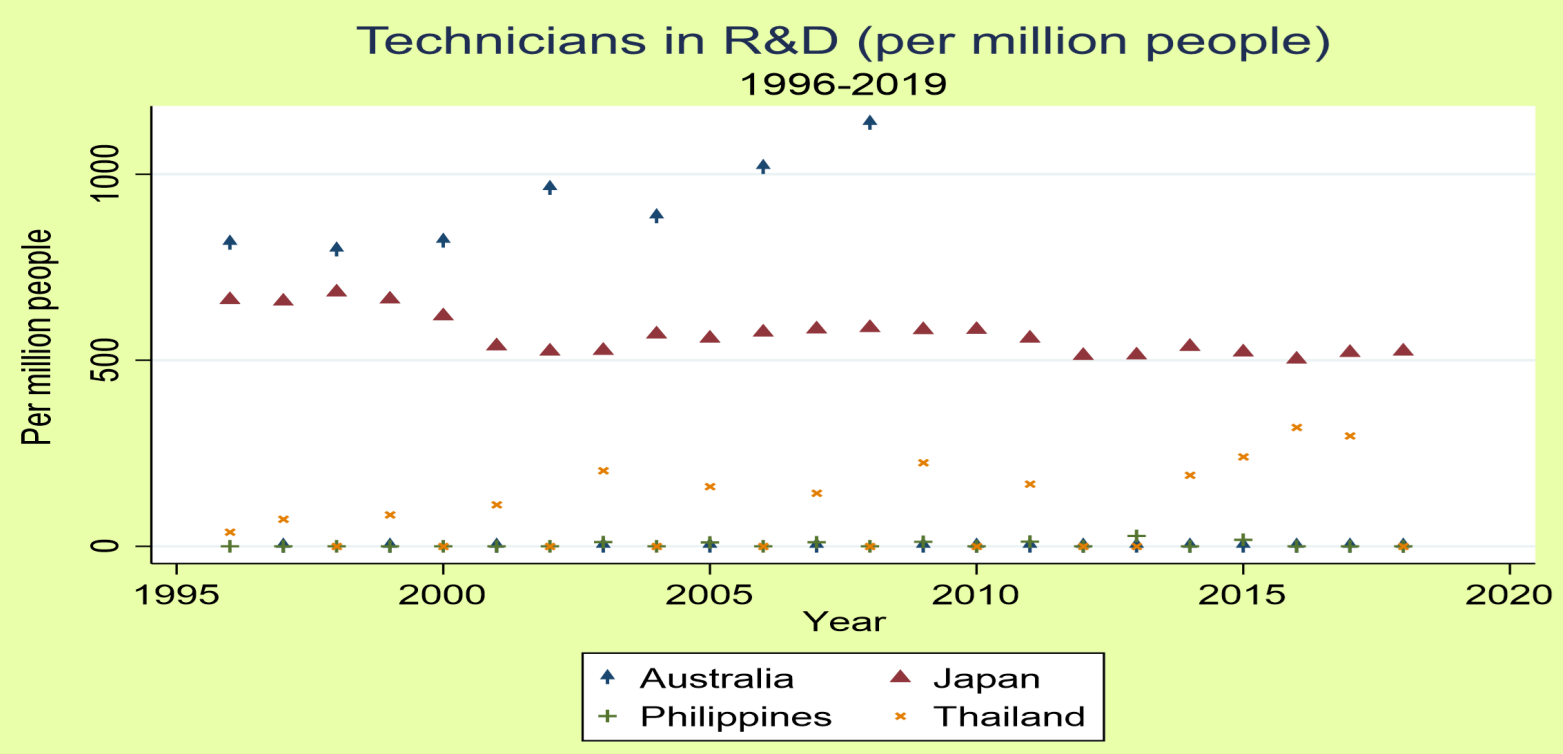

FIGURE 4 Technicians in Research and Development every Million people

\section{APPROVED AND REGISTERED PATENT \\ 1980-2019}
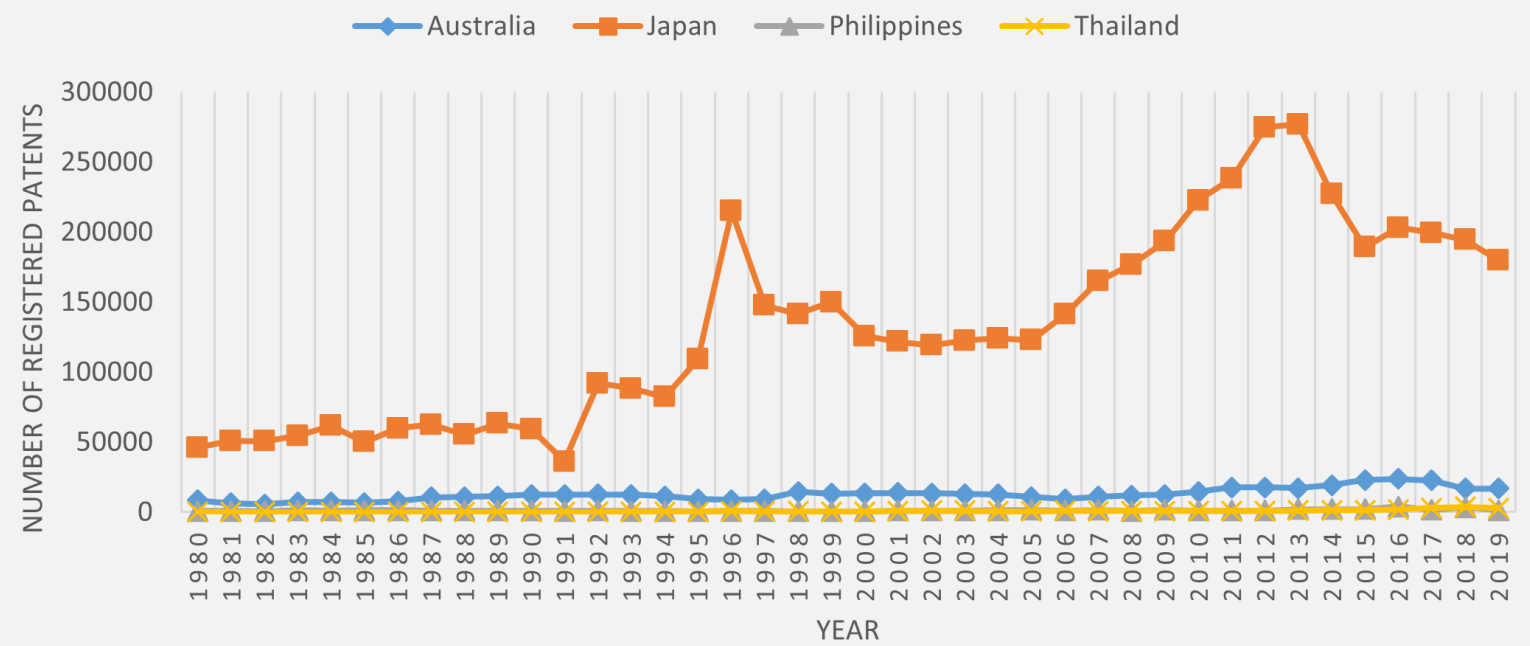

FIGURE 5 Approved and Registered Patent of four Countries in Asia-Pacific Region

manufactured or provided by a particular individual or business. It protects the mark owner by granting him or her the exclusive right to use the mark in identifying products or services, or the right to permit others to use the mark in exchange for payment (World Intellectual Property Organization, 2021). In Japan, trademarks are applied and employed based on Trademark Act (, Shōhyō-hō). According to Bahraini (2003) and Yasuda (2007), intellectual property in Japan fosters economic development. Concerning registered trademarks in Australia, it ranked twelfth among countries that have the highest number of trademarks in 2018. Moreover, Thailand has a greater number of registered trademarks compared to the Philippines. It is evident that Thailand 
is highly developing. The trademark in the Philippines is not fully acknowledged and various intellectual property issues in the country remain unresolved (Nguyen, 2020; ITA, 2021; IPOPhil, 2020).

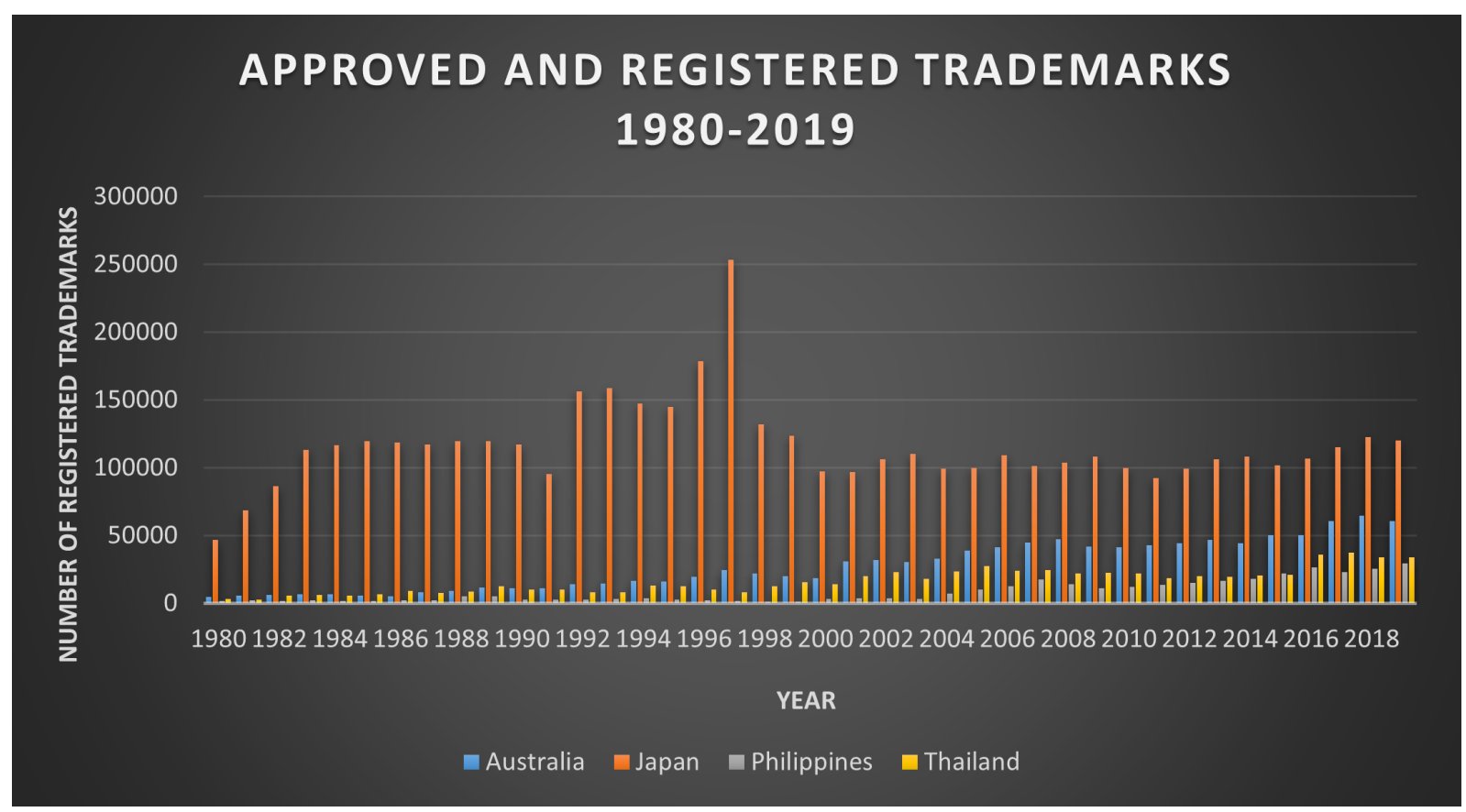

FIGURE 6 Approved and Registered Trademarks of four Countries in Asia-Pacific Region

Japan has the greatest number of scientific and technical journal articles among the countries observed as shown in Figure 7. According to SCI and SSCI (2020), Japan ranked fifth in the list of countries per number of scientific and technical journal articles. Australia ranked fourteenth, while the Philippines and Thailand ranked 63 and 31, respectively. With the foregoing, it is evident that the Philippines was left behind and is lagging on research and development performance among neighboring countries.

The number of researchers per country is related to RD and is expressed as the number of researchers per million population. According to UNESCO Institute for Statistics (2021), researchers are individuals who perform research to refine or establish organizational methods principles, hypotheses, models, strategies, instrumentation, and software. Based on Figure 8, Japan has the highest number of researchers and ranked fifteenth per OECD (2019), while the Philippines has the least. In reference to Figure 4, Australia's technician per million people is greater compared with its researchers per million people. Thailand's researchers per million people are also gearing up, while of that Philippines is decreasing due to increase on population, thus lesser researchers are produced and have been engaged in such specialization.

\section{2 | Nexus of Science Technology Input through Research and Development Indicators, and Economic Growth}

To ravel the nexuses of research and development indicators, and economic growth, descriptive statistics is an important tool for scrutinizing the descriptions of variables. Table 2 presents the characteristics of the variables used. There are 160 observations used in the study. These samples were formed from 40-year representations of 4 countries in the Asia-Pacific Region with corresponding RD indicators and economic growth variables. 


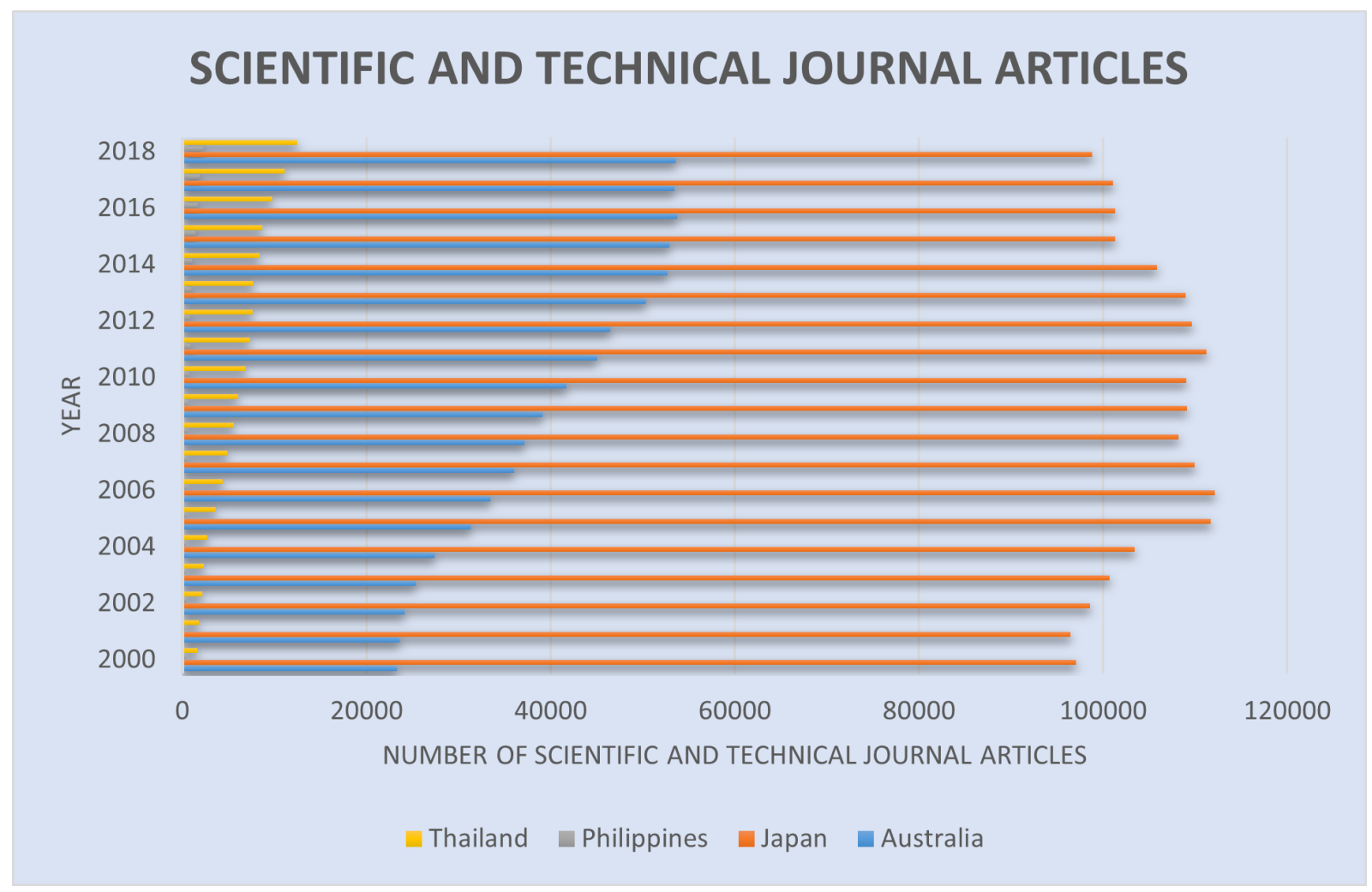

FIGURE 7 Scientific and Technical Journal Articles of four Countries in Asia-Pacific Region

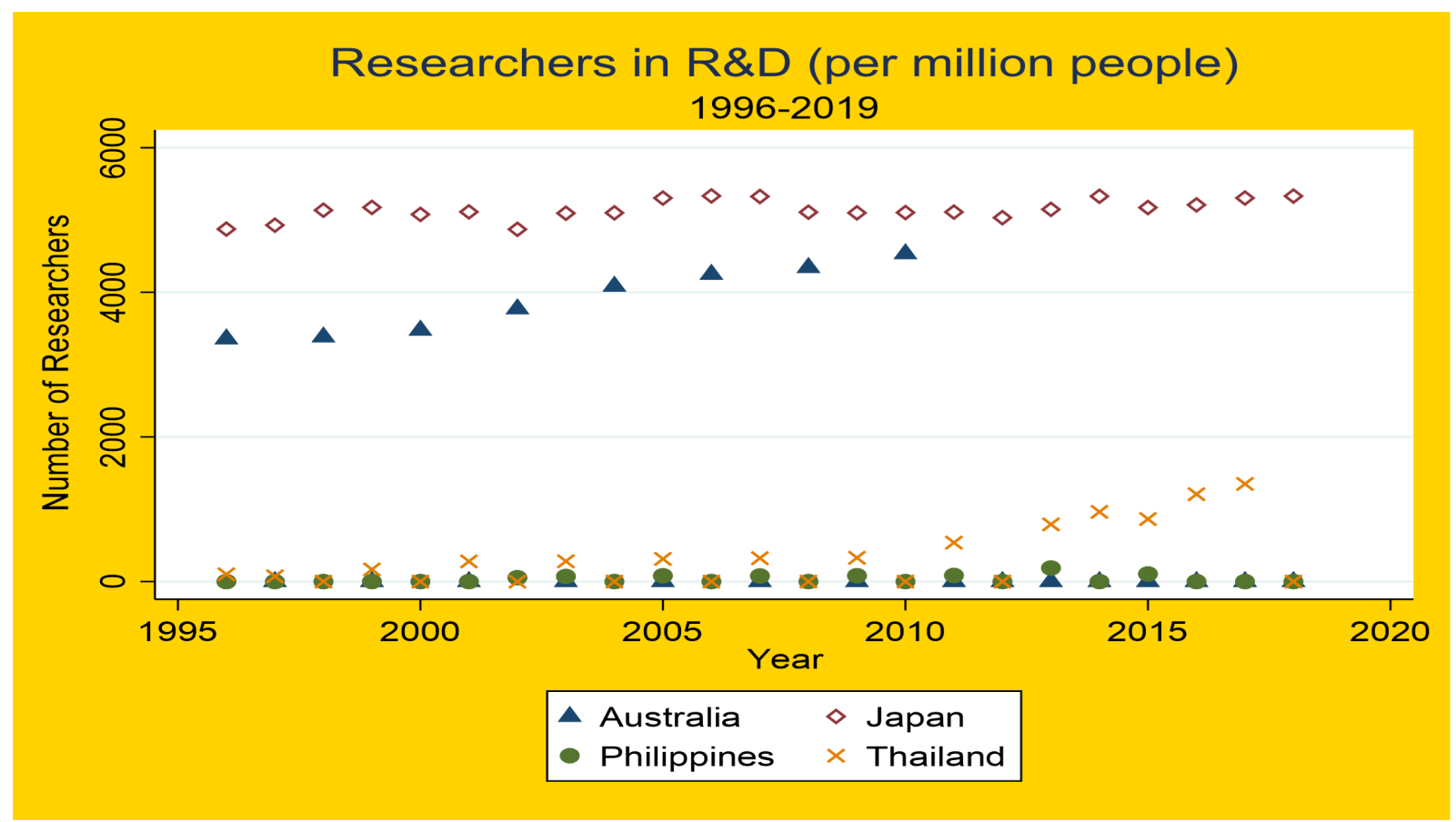

FIGURE 8 Researchers in Research and Development per Million People 
TABLE 2 Descriptive Statistics of Research and Development Indicators, and Economic Growth

\begin{tabular}{|c|c|c|c|c|c|c|c|c|c|}
\hline \multirow[t]{2}{*}{ Country } & \multicolumn{2}{|c|}{ DescriptiveGrowth } & \multirow[b]{2}{*}{$\begin{array}{l}\text { Growth } \\
\text { Rate of } \\
\text { Gross } \\
\text { National } \\
\text { Income } \\
\text { per } \\
\text { Capita }\end{array}$} & \multirow[b]{2}{*}{$\begin{array}{l}\text { Research } \\
\text { and } \\
\text { Devel- } \\
\text { opment } \\
\text { Expen- } \\
\text { ditures }\end{array}$} & \multirow{2}{*}{\multicolumn{2}{|c|}{$\begin{array}{c}\text { TechniciansApproved } \\
\text { Patents }\end{array}$}} & \multirow{2}{*}{$\begin{array}{l}\text { Approved } \\
\text { Trade- } \\
\text { marks }\end{array}$} & \multirow[b]{2}{*}{$\begin{array}{l}\text { Scientific } \\
\text { and } \\
\text { Tech- } \\
\text { nical } \\
\text { Journal } \\
\text { Articles }\end{array}$} & \multirow[t]{2}{*}{ Researchers } \\
\hline & $\begin{array}{l}\text { Statis- } \\
\text { tics }\end{array}$ & $\begin{array}{l}\text { Rate of } \\
\text { Gross } \\
\text { Domes- } \\
\text { tic } \\
\text { Prod- } \\
\text { uct per } \\
\text { Capita }\end{array}$ & & & & & & & \\
\hline \multirow[t]{6}{*}{ Australia } & Mean & 1.690 & 1.636 & 1.213 & 1.000 & 2.870 & 7.788 & 2.713 & 1.000 \\
\hline & Std Dev & 1.513 & 1.532 & 0.584 & 0.000 & 15.631 & 16.530 & 3.138 & 0.000 \\
\hline & Maximum & 4.027 & 4.177 & 2.404 & 1.000 & 56.997 & 67.784 & 14.362 & 1.000 \\
\hline & Minimum & -3.436 & -2.452 & 0.000 & 1.000 & -24.963 & -19.089 & -0.656 & 1.000 \\
\hline & Median & 1.754 & 1.483 & 1.000 & 1.000 & 0.534 & 3.576 & 1.000 & 1.000 \\
\hline & Variance & 2.289 & 2.347 & 0.341 & 0.000 & 244.336 & 273.226 & 9.848 & 0.000 \\
\hline \multirow[t]{6}{*}{ Japan } & Mean & 1.693 & 1.758 & 2.219 & -0.074 & 6.695 & 4.002 & 0.610 & 0.690 \\
\hline & Std Dev & 2.082 & 2.160 & 1.072 & 3.542 & 31.638 & 18.580 & 1.850 & 1.833 \\
\hline & Maximum & 6.330 & 6.370 & 3.400 & 8.360 & 155.125 & 63.686 & 7.986 & 4.573 \\
\hline & Minimum & -5.405 & -5.531 & 1.000 & -13.045 & -39.227 & -47.856 & -4.298 & -4.726 \\
\hline & Median & 1.655 & 1.897 & 2.883 & 1.000 & 1.182 & 1.707 & 1.000 & 1.000 \\
\hline & Variance & 4.335 & 4.666 & 1.149 & 12.545 & 1000.993 & 345.230 & 3.424 & 3.361 \\
\hline \multirow[t]{6}{*}{ Philippine } & Mean & 1.742 & 2.006 & 0.776 & 1.000 & 9.398 & 13.597 & 5.881 & 1.757 \\
\hline & Std Dev & 3.509 & 3.595 & 0.395 & 0.000 & 45.257 & 45.243 & 10.761 & 4.788 \\
\hline & Maximum & 5.561 & 5.718 & 1.000 & 1.000 & 128.571 & 174.095 & 34.379 & 31.283 \\
\hline & Minimum & -9.812 & -11.782 & 0.000 & 1.000 & -58.937 & -43.517 & -12.256 & 1.000 \\
\hline & Median & 2.293 & 2.871 & 1.000 & 1.000 & -1.189 & 8.805 & 1.000 & 1.000 \\
\hline & Variance & 12.310 & 12.924 & 0.156 & 0.000 & 2048.186 & 2046.944 & 115.804 & 22.926 \\
\hline \multirow[t]{6}{*}{ Thailand } & Mean & 4.047 & 3.984 & 0.661 & 4.458 & 29.422 & 9.487 & 5.993 & 2.477 \\
\hline & Std Dev & 3.638 & 3.693 & 0.381 & 15.426 & 74.703 & 29.980 & 7.367 & 7.326 \\
\hline & Maximum & 11.336 & 11.484 & 1.004 & 90.780 & 425.000 & 125.010 & 31.107 & 39.758 \\
\hline & Minimum & -8.742 & -9.580 & 0.000 & -7.140 & -45.781 & -22.306 & 0.782 & -10.289 \\
\hline & Median & 3.764 & 3.845 & 1.000 & 1.000 & 10.486 & 1.589 & 1.000 & 1.000 \\
\hline & Variance & 13.233 & 13.637 & 0.146 & 237.950 & 5580.536 & 898.817 & 54.276 & 53.674 \\
\hline \multirow[t]{6}{*}{ Total } & Mean & 2.293 & 2.346 & 1.217 & 1.596 & 12.096 & 8.718 & 3.799 & 1.481 \\
\hline & Std Dev & 2.987 & 3.026 & 0.905 & 8.024 & 47.778 & 29.769 & 7.080 & 4.483 \\
\hline & Maximum & 11.336 & 11.484 & 3.400 & 90.780 & 425.000 & 174.095 & 34.379 & 39.758 \\
\hline & Minimum & -9.812 & -11.782 & 0.000 & -13.045 & -58.937 & -47.856 & -12.256 & -10.289 \\
\hline & Median & 2.348 & 2.544 & 1.000 & 1.000 & 1.595 & 2.735 & 1.000 & 1.000 \\
\hline & Variance & 8.922 & 9.154 & 0.819 & 64.384 & 2282.757 & 886.191 & 50.129 & 20.097 \\
\hline
\end{tabular}


All inputs were expressed in percentages and growth rates which were statistically manipulated to achieve reliability and comparability clauses. The average GDP per capita growth rate is $1.690 \%$ with a standard deviation of 1.513 in Australia. Concerning Japan's Growth Rate of Gross National Income per Capita, the minimum and maximum values are 6.330 and -5.405, respectively. Moreover, the median and variance in the Philippines and Thailand's GDP per capita are 2.293, 12.310, 3.764, and 13.233, respectively. Moreover, the average values and entirety of relevant measures of central tendency of independent variables are also shown in the table.

Table 3 shows the characteristics of the panel data. Country ID was used and declared as a panel. There are four countries involved, namely: Australia, Japan, the Philippines, and Thailand. It is conclusive that the first two countries are developed while the two remaining countries are developing economies. The data run from 1980 to 2019, or a total of 40 years. The Growth Rate of Gross Domestic Product and Gross National Income per Capita in average is 2.29 and 2.35, respectively. Japan has the highest expenditure on research and development expressed in percentage of GDP, while the Philippines has the least. Australia has the highest Gross Domestic Product and Gross National Income per Capita while the Philippines has the lowest. Furthermore, relevant characterization of the panel data is tabulated herein below.

The results of the panel regression were generated through random- and fixed effects. It is evident that the nexus between the Growth Rate of Gross Domestic Product per Capita and Research and development indicators is weak to negligible. The results

TABLE 3 Characteristics of Panel Data

\begin{tabular}{|c|c|c|c|c|c|c|}
\hline Variable & Parameters & Mean & Std. Dev. & Min & Max & Observations \\
\hline \multirow{3}{*}{$\begin{array}{l}\text { Growth Rate of } \\
\text { Gross Domestic } \\
\text { Product per Capita }\end{array}$} & overall & \multirow[t]{3}{*}{2.292838} & 2.987045 & -9.811554 & 11.3365 & $\mathrm{~N}=160$ \\
\hline & between & & 1.169626 & 1.689785 & 4.04691 & $\mathrm{n}=4$ \\
\hline & within & & 2.808909 & -10.49575 & 9.58238 & $\mathrm{~T}=40$ \\
\hline \multirow{3}{*}{$\begin{array}{l}\text { Growth Rate of } \\
\text { Gross National } \\
\text { Income per Capita }\end{array}$} & overall & \multirow[t]{3}{*}{2.345767} & 3.025502 & -11.78178 & 11.4839 & $\mathrm{~N}=160$ \\
\hline & between & & 1.103 & 1.635535 & 3.98409 & $\mathrm{n}=4$ \\
\hline & within & & 2.869751 & -11.44151 & 9.84563 & $\mathrm{~T}=40$ \\
\hline \multirow{3}{*}{$\begin{array}{l}\text { Research and } \\
\text { Development } \\
\text { Expenditures }\end{array}$} & overall & \multirow[t]{3}{*}{1.21747} & 0.9049862 & 0 & 3.40022 & $\mathrm{~N}=160$ \\
\hline & between & & 0.7091367 & 0.661361 & 2.21949 & $\mathrm{n}=4$ \\
\hline & within & & 0.6629267 & -0.002024 & 2.40769 & $\mathrm{~T}=40$ \\
\hline \multirow{3}{*}{ Technicians } & overall & \multirow[t]{3}{*}{1.596154} & 8.023937 & -13.04493 & 90.7796 & $\mathrm{~N}=160$ \\
\hline & between & & 1.974151 & -0.073769 & 4.45839 & $\mathrm{n}=4$ \\
\hline & within & & 7.838509 & -11.375 & 87.9174 & $\mathrm{~T}=40$ \\
\hline \multirow{3}{*}{ Approved Patents } & overall & \multirow[t]{3}{*}{12.09637} & 47.77821 & -58.9366 & 425 & $\mathrm{~N}=160$ \\
\hline & between & & 11.85692 & 2.869957 & 29.4221 & $\mathrm{n}=4$ \\
\hline & within & & 46.65463 & -63.10722 & 407.674 & $\mathrm{~T}=40$ \\
\hline \multirow{3}{*}{$\begin{array}{l}\text { Approved } \\
\text { Trademarks }\end{array}$} & overall & \multirow[t]{3}{*}{8.718336} & 29.76895 & -47.85606 & 174.095 & $\mathrm{~N}=160$ \\
\hline & between & & 3.978962 & 4.002277 & 13.5967 & $\mathrm{n}=4$ \\
\hline & within & & 29.56758 & -48.39536 & 169.217 & $\mathrm{~T}=40$ \\
\hline \multirow{3}{*}{$\begin{array}{l}\text { Scientific and } \\
\text { Technical Journal } \\
\text { Articles }\end{array}$} & overall & \multirow[t]{3}{*}{3.79912} & 7.080171 & -12.25642 & 34.3793 & $\mathrm{~N}=160$ \\
\hline & between & & 2.613672 & 0.610023 & 5.99254 & $\mathrm{n}=4$ \\
\hline & within & & 6.706202 & -14.33805 & 32.2977 & $\mathrm{~T}=40$ \\
\hline \multirow{3}{*}{ Researchers } & overall & \multirow[t]{3}{*}{1.481051} & 4.482989 & -10.28947 & 39.7581 & $\mathrm{~N}=160$ \\
\hline & between & & 0.8010279 & 0.690171 & 2.47697 & $\mathrm{n}=4$ \\
\hline & within & & 4.428649 & -11.28539 & 38.7622 & $\mathrm{~T}=40$ \\
\hline
\end{tabular}


TABLE 4 Results of Panel Regression on Growth Rate of Gross Domestic Product per Capita, and Research and Development Indicators

\begin{tabular}{lcccc}
\hline Gross Domestic Product Per capita Growth Rates & Coef. & Std. Err. & TStat & P Value \\
\hline \hline Random Effects & & & & \\
Research and Development Expenditures & -0.5128217 & 0.2827659 & -1.81 & 0.07 \\
Technicians in RD per Million people & -0.0549099 & 0.0296991 & -1.85 & 0.064 \\
Approved Patents & 0.005192 & 0.0048802 & 1.06 & 0.287 \\
Approved Trademark & 0.0056901 & 0.0078611 & 0.72 & 0.469 \\
Scientific and Technical Journals & 0.0504499 & 0.0351715 & 1.43 & 0.151 \\
Researchers in RD per million & 0.0086032 & 0.0527055 & 0.16 & 0.87 \\
_cons & 2.688009 & 0.5051688 & 5.32 & 0 \\
Fixed Effects & & & & \\
Research and Development Expenditures & 0.3622119 & 0.3452015 & 1.05 & 0.296 \\
Technicians in RD per Million people & -0.0745533 & 0.0287464 & -2.59 & 0.01 \\
Approved Patents & 0.0011795 & 0.0047683 & 0.25 & 0.805 \\
Approved Trademark & 0.0073667 & 0.0075274 & 0.98 & 0.329 \\
Scientific and Technical Journals & 0.0441488 & 0.0338865 & 1.3 & 0.195 \\
Researchers in RD per million & -0.0031114 & 0.0504869 & -0.06 & 0.951 \\
cons & 2.611208 & 0.5394988 & 4.84 & 0 \\
\hline
\end{tabular}

show that the nexus between dependent and independent variables is not significant. All computed P-Values are higher compared with the alpha level (of 0.05 threshold). They have negligible to moderate positive and negative associations. Table 4 depicts the first causality analysis incorporating the four countries and analyzing the panel data holistically. The findings imply that the $\mathrm{RD}$ indicators have no significant relationship with the economic growth variables of the countries involved. Such claim argues with the contexts of Licheng (2011) that there is a close tie between economic growth and science and technology inputs in the three primary economic regions in coastal areas of China. Hence, the result fails to reject the null hypothesis.

Tackling the results of the panel econometrics shown in Table 5 it is apparent that the nexus of the Growth Rate of Gross National Income per Capita, and Research and Development Indicators is also weak to negligible. The results assert that the relationship between dependent and independent variables is not significant. All computed p-values are higher compared with the alpha level (of 0.05 threshold). They also have negligible to moderate positive and negative associations. This is the second causality analysis that the researcher employed. It is therefore conclusive that the RD indicators have no significant relationship with the economic growth variables of countries involved. This claim differs from Gaillard (2010) revealing that science and technology inputs contribute to the economic development of developing countries. Hence, the result fails to reject the null hypothesis.

Holistically, the results assert that the nexus between economic growth and science and technology input is weak to negligible, and insignificant. However, to expand causality analyses, the researcher split the panel data into two clusters. The first-panel data set reflects that in Australia and Japan, the developed economies. The second-panel data set contains the data of the Philippines and Thailand, the developing economies. Interestingly, the result of panel regression on the data containing developed countries is materially distinct from the holistic panel data of four countries. As to developed economies, Table 6 shows that science and technology input through RD indicators significantly influence the economic growth both in growth rates of GDP and GNI per capita.

The nexus of dependent and independent variables are high or robust. Such findings aligned with the conclusions of Peled (2001), UNESCO, and UNIDO (2021). The research and development highly contributed to the economic growth and progress of developed economies around the world. For instance, Israel and South Korea are known as research and development leaders, which have the highest investments in RD. Their economy progress - exports improved, human capital was highly developed, the field of medicine and sciences were recognized worldwide, infrastructure is heavy-duty, total factor productivity is increasing, and national income rises. According to Oshima (1973) and Branstetter (2004), the research and development efforts of Japan have contributed a lot to the technological advancement of the country which increased economic efficiency and national output. Likewise, per the Australian government (1995, 2012, 2017) and Millist et. al. (2017), a weighty contribution has been 
TABLE 5 Results of Panel Regression on Growth Rate of Gross National Income per Capita, and Research and Development Indicators

\begin{tabular}{lcccr}
\hline Gross National Income Per capita Growth Rate & Coef. & Std. Err. & TStat & P Value \\
\hline \hline Random Effects & & & & \\
Research and Development Expenditures & -0.5283847 & 0.2872632 & -1.84 & 0.066 \\
Technicians in RD per Million people & -0.059891 & 0.0301715 & -1.99 & 0.047 \\
Approved Patents & 0.0064734 & 0.0049578 & 1.31 & 0.192 \\
Approved Trademark & -0.0019734 & 0.0079862 & -0.25 & 0.805 \\
Scientific and Technical Journals & 0.0410255 & 0.0357309 & 1.15 & 0.251 \\
Researchers in RD per million & 0.0281215 & 0.0535438 & 0.53 & 0.599 \\
_cons & 2.826044 & 0.5132033 & 5.51 & 0.000 \\
Fixed Effects & & & & \\
Research and Development Expenditures & 0.341712 & 0.3549952 & 0.96 & 0.337 \\
Technicians in RD per Million people & -0.0774945 & 0.029562 & -2.62 & 0.01 \\
Approved Patents & 0.0027091 & 0.0049036 & 0.55 & 0.581 \\
Approved Trademark & -0.0006682 & 0.007741 & -0.09 & 0.931 \\
Scientific and Technical Journals & 0.0330979 & 0.0348479 & 0.95 & 0.344 \\
Researchers in RD per million & 0.0161646 & 0.0519193 & 0.31 & 0.756 \\
_cons & 2.708856 & 0.5548049 & 4.88 & 0.000 \\
\hline
\end{tabular}

TABLE 6 Results of Panel Regression on Economic Growth Variables and Research and Development Indicators of Developed Economies

\begin{tabular}{lcccr}
\hline Economic Growth Variables & Coef. & Std. Err. & TStat & P Value \\
\hline \hline Growth Rate of Gross Domestic Product per Capita & & & & \\
Random Effects & -0.5541705 & 0.2226517 & -2.49 & 0.013 \\
Fixed Effects & -0.7149057 & 0.2430417 & -2.94 & 0.004 \\
& & & & \\
Growth Rate of Gross National Income per Capita & & & & \\
Random Effects & -0.4695426 & 0.2322745 & -2.02 & 0.043 \\
Fixed Effects & -0.6333565 & 0.2537438 & -2.5 & 0.015 \\
\hline
\end{tabular}

driven by research and development for the improvement of economic functions and processes in the country, especially in rural sectors. Thus, science and technology input through research and development indicators foster economic growth in developed economies. Hence, the result rejects the null hypothesis. Surprisingly, when the panel data was split into two and the cluster for developing countries was tested, the results differ from that panel for developed economies. Table 7 shows that there is no robust nexus between economic growth and RD Indicators. Both GDP and GNI per capita have weak to negligible associations with economic growth. It is evident that research and development are not fully practiced in developing countries.

Such observation can be attested by the substantiation of graphs which can be found in preceding discussions. Philippines and Thailand have lesser RD expenditure, a fewer number of technicians and researchers, and a lesser number of scientific and technical journals, patents, and trademarks compared to Japan and Australia. This result is parallel to the arguments of UNCTAD (2006) and Gaillard (2010) that developing countries have scarce statistics concerning RD, and utilization of RD for technological advancement and economic growth is not yet visible. Hence, the result fails to reject the null hypothesis. 
TABLE 7 Results of Panel Regression on Economic Growth Variables and Research and Development Indicators of Developing Economies

\begin{tabular}{lcccr}
\hline Economic Growth Variables & Coef. & Std. Err. & TStat & P Value \\
\hline \hline Growth Rate of Gross Domestic Product per Capita & & & & \\
Random Effects & -1.617819 & 1.30027 & -1.24 & 0.213 \\
Fixed Effects & -2.205871 & 1.224698 & -1.8 & 0.076 \\
& & & & \\
Growth Rate of Gross National Income per Capita & & & & \\
Random Effects & -1.634194 & 1.634194 & -1.634194 & 1.634194 \\
Fixed Effects & -1.311902 & 1.311902 & -1.311902 & 1.311902 \\
\hline
\end{tabular}

TABLE 8 Comparison of Research and Development Indicators, and Economic Growth Variables

\begin{tabular}{lcccc}
\hline Groups & Count & Sum & Average & Variance \\
\hline Growth Rate of Gross Domestic Product per Capita & 4 & 9.171353273 & 2.292838318 & 1.368025627 \\
Growth Rate of Gross National Income per Capita & 4 & 9.383066154 & 2.345766538 & 1.21660979 \\
Research and Development Expenditures & 4 & 4.86988075 & 1.217470188 & 0.502874918 \\
Technicians in RD per Million people & 4 & 6.384616927 & 1.596154232 & 3.897270877 \\
Approved Patents & 4 & 48.38549014 & 12.09637254 & 140.586626 \\
Approved Trademark & 4 & 34.87334376 & 8.71833594 & 15.83213672 \\
Scientific and Technical Journals & 4 & 15.19647931 & 3.799119829 & 6.831278867 \\
Researchers in RD per million & 4 & 5.924205231 & 1.481051308 & 0.641645643 \\
\hline
\end{tabular}

TABLE 9 Analysis on Variance of Research and Development Indicators, and Economic Growth Variables

\begin{tabular}{lcccccc}
\hline Variation Sources & SS & df & MS & F & P-value & F crit \\
\hline \hline Between Clusters & 452.2881615 & 7 & 64.6125945 & 3.024996717 & 0.019921 & 2.422629 \\
Within Clusters & 512.6294052 & 24 & 21.35955855 & & & \\
\hline \multirow{2}{*}{ Total } & $\mathbf{9 6 4 . 9 1 7 5 6 6 8}$ & & & & & \\
& $\mathbf{3 1}$ & & & & \\
\hline
\end{tabular}

\section{3 | Variations of Science Technology Input through Research and Development Indicators, and Economic Growth}

Table 8 reflects the comparison of Research and Development Indicators and Economic Growth Variables regarding clustered statistics.

Table 9 reveals that there is a significant difference among the means of research and development indicators and economic growth variables of four countries in Asia-Pacific. The computed p-value is 0.019921 which is lower than the critical value. Thus, the null hypothesis should be rejected. The science and technology input through RD indicators and the economic growth of the four countries are different statistically.

\section{4 | Evaluation of Science Technology Input through Research and Development Indicators as driver/predictor of Economic Growth}

The results of panel regression assert that the Science Technology Input through Research and Development Indicators can only be used as a driver or predictor of economic growth in developed countries, such as in Japan and Australia but not yet in developing countries, such as the Philippines and Thailand. The results of the two-panel data are econometrically different 
from each other. However, when the panel data for the four countries were evaluated, the result shows that the RD indicators cannot be utilized as a driver or predictor of economic growth among the countries involved. It is apparent that the panel data for developing countries outweighed the panel data attributable to developed economies when the two sets of panel data were lumped and tested. It is because the causality of RD indicators to developing countries is linked to lower R-Squared as compared to developed economies. With the foregoing, the science and technology input through RD indicators is a driver or predictor of economic growth, particularly in developed and industrialized economies. Such claim is synchronous with the empirics of Solow (1957), Lortie (1984), Romer (1999), OECD (2007), Khan (2015), Kim, et al (2020), and UNESCO (2021).

\section{CONCLUSION AND RECOMMENDATIONS}

Through the panel econometrics and causality analyses presented hereinabove, the researcher concludes that among the four countries tested in the study, Japan has the highest and sufficient number of RD indicators, Australia has the highest rate of economic growth variables, Thailand is well-developing and depicts an increasing trend of economic and RD functioning, while Philippines has the least economic and RD performance. Concerning the nexus of economic growth variables and RD indicators, the first set of panel data unraveled that there is a robust association between variables involved, thus it is concluded that the science and technology input through RD indicators can be effectively used as driver or predictor of economic growth in developed economies. However, the nexus of economic growth variables and RD indicators on the second set of panel data unraveled that weak to negligible association among variables involved is dominant, thus it is concluded that the science and technology input through RD indicators cannot be utilized yet as a driver or predictor of economic growth in developing economies, since investment in RD of such countries are not adequate and some information concerning RD indicators is scarce. Furthermore, the combined panel data from two aforementioned panel data sets unraveled weak to moderate associations of variables involved, thus it is concluded that RD indicators cannot be reliably utilized yet as a driver or predictor of economic growth when the data were lumped all together. Such outcome is concluded due to statistical difference of panel data and means of economic growth variables and RD indicators, which were derived from analysis on variance. With the foregoing, a preliminary assertion can also be drawn that the economic performance of Japan and Australia is far ahead of Thailand and the Philippines. The analytical results unraveled that the research and development expenditure as expressed in percentage of GDP is the major determinant of economic growth in this study, which has the most robust significance level, particularly in developed economies. Concerning, approved patents and trademarks, these indicators are partly attributable to research and development but more on total factor productivity or technological advancement which is of the outside scope of the study. The number of scientific and technical journals represents the output of the RD expenditure, thus is it strongly correlated to the latter. Regarding the number of technicians and researchers per million, these indicators represent the input of RD expenditure, thus also highly associated with the latter. The scientific and technical input has the greatest degree of contribution to the economic growth in Japan and Australia.

Based on conclusions, the researcher recommends that Japan and Australia should maintain their research and development investments and activities, as it promotes economic development. However, more budget should be allotted and more funds should be given to ensure the adequacy, efficiency, and effectiveness of expenditure on research and development of developing countries. Higher funds or expenditure reflects higher RD performance such as that in developed economies. Hence, to promote industrialization and technological advancement in the Philippines and Thailand, it is suggested that more RD expenditure and activities should be invested and catered, respectively. Furthermore, the focus of the study dealt with RD indicators and economic growth among four countries in the Asia-Pacific region which are quite comprehensive econometrically and generic scientifically. It is indicative that further study on the specific nature and explicit types of research and development among four countries be conducted, as well as its utilization and applications to determine what kind or which type of research and development activities foster economic vitality.

\section{References}

Asian financial crisis I Causes, Effects, \& Facts. (n.d.). Retrieved 2021-10-31, from https://www.britannica.com/event/ Asian-financial-crisis

Australia. Dept. of Agriculture, F. a. F. (2012). Rural research and development policy statement. Canberra, A.C.T.: DAFF. OCLC: 801357752. 
Bahraini, Z. (2003). A Comparative Study on Japanese Trademark Protection System with Iranian Trademark Protection System (Tech. Rep.). Tokyo: Industrial Property Office of I.R. of Iran.

Becker, G. S., \& Murphy, K. M. (1992, November). The Division of Labor, Coordination Costs, and Knowledge. The Quarterly Journal of Economics, 107(4), 1137-1160. Retrieved 2021-10-31, from https://academic.oup.com/qje/article -lookup/doi/10.2307/2118383 doi: 10.2307/2118383

Branstetter, L., \& Ug, K. H. (2004, May). The Restructuring Of Japanese Research And Development: The Increasing Impact Of Science On Japanese R\&D (Discussion papers No. 04021). Research Institute of Economy, Trade and Industry (RIETI). Retrieved from https://ideas.repec.org/p/eti/dpaper/04021.html

Gaillard, J. (2010, March). Measuring Research and Development in Developing Countries: Main Characteristics and Implications for the Frascati Manual. Science, Technology and Society, 15(1), 77-111. Retrieved 2021-10-31, from http://journals.sagepub.com/doi/10.1177/097172180901500104 doi: 10.1177/097172180901500104

Guellec, D., \& van Pottelsberghe de la Potterie, B. (2001). Ramp;d and productivity growth. Retrieved from https://www . oecd-ilibrary.org/content/paper/652870318341 doi: https://doi.org/https://doi.org/10.1787/652870318341

Hill, H. (1986). The philippine economy in 1985: The decline continues. Southeast Asian Affairs, 239-257. Retrieved from http://www.jstor.org/stable/27908554

KHAN, J. (2015). The role of research and development in economic growth: A review. Journal of Economics Bibliography, 2(3), 128-133. Retrieved from/http://www.kspjournals.org/index.php/JEB/article/view/480

Kim, J., \& Castillejos-Petalcorin, C. (2020). The Role of Government Research \& Development in Fostering Innovation in Asia (Tech. Rep.). Asian Development Bank.

Kravis, I. B., Heston, A. W., \& Summers, R. (1978, June). Real GDP Per Capita for More Than One Hundred Countries. The Economic Journal, 88(350), 215. Retrieved 2021-10-31, from https://academic.oup.com/ej/article/88/350/ 215-242/5220607 doi: 10.2307/2232127

Licheng, W. (2011). Science \& Technology Input and Economic Growth: An Empirical Analysis Based on the Three Major Coastal Economic Regions of China. Energy Procedia, 5, 1779-1783. Retrieved 2021-10-31, from https:// linkinghub.elsevier.com/retrieve/pii/S1876610211012392 doi: 10.1016/j.egypro.2011.03.303

Lortie, P. (1984, June). Fostering Economic Growth. Canadian Public Policy / Analyse de Politiques, 10(2), 225. Retrieved 2021-10-31, from https://www.jstor.org/stable/3550946?origin=crossref doi: 10.2307/3550946

MEXT : 2.1 RD Expenditures. (n.d.). Retrieved 2021-10-31, from https://www.mext.go.jp/en/publication/ whitepaper/title03/detail03/sdetail03/sdetail03/1372934.htm

Millist, N., Chancellor, W., \& Jackson, T. (2017). Rural research, development and extension investment in Australia. Retrieved 2021-10-31, from http://rgdoi.net/10.13140/RG.2.2.30971.57121 doi: 10.13140/RG.2.2.30971.57121

Niksch, L. A. (1989, February). Thailand in 1988: The Economic Surge. Asian Survey, 29(2), 165-173. Retrieved 202110-31, from https://online.ucpress.edu/as/article/29/2/165/22556/Thailand-in-1988-The-Economic -Surge doi: 10.2307/2644576

Office of National Higher Education Science Research and Innovation Policy Council. (n.d.). Retrieved 2021-10-31, from https://www.nxpo.or.th/th/en/

Organisation for Economic Co-operation and Development. (2007). Innovation and Growth: Rationale for an Innovation Strategy (Tech. Rep.). Paris, France: Organisation for Economic Co-operation and Development.

Oshima, K. (1973). Research and Development and Economic Growth in Japan. In B. R. Williams (Ed.), Science and Technology in Economic Growth (pp. 310-334). London: Palgrave Macmillan UK. Retrieved 2021-10-31, from http://link .springer.com/10.1007/978-1-349-01731-7_12 doi: 10.1007/978-1-349-01731-7,2

Peled, D. (2001). Defense R\&D and Economic Growth in Israel: A Research Agenda, Science, Technology and the Economy Program STE-WP-4 (Tech. Rep.). Haifa Israel: Samuel Neaman Institute. Retrieved from https://www.neaman.org .il/EN/Defense-RD-Economic-Growth-Israel-Research-Agenda-STE-WP-4

Raghupathi, V., \& Raghupathi, W. (2017, December). Innovation at country-level: association between economic development and patents. Journal of Innovation and Entrepreneurship, 6(1), 4. Retrieved 2021-10-31, from http://innovation -entrepreneurship.springeropen.com/articles/10.1186/s13731-017-0065-0 doi: 10.1186/s13731-0170065-0

Romer, P. M. (1990). Endogenous technological change. Journal of Political Economy, 98(5), S71-S102. Retrieved from http://www.jstor.org/stable/2937632 
Sarwar, A., Khan, M. A., Sarwar, Z., \& Khan, W. (2021, April). Financial development, human capital and its impact on economic growth of emerging countries. Asian Journal of Economics and Banking, 5(1), 86-100. Retrieved 2021-1031, from https://www.emerald.com/insight/content/doi/10.1108/AJEB-06-2020-0015/full/html doi: 10.1108/AJEB-06-2020-0015

Sicat, G. P. (1984). The philippines in 1983: Economic crisis in perspective. Southeast Asian Affairs, 249-265. Retrieved from http://www.jstor.org/stable/27908505

Solow, R. M. (1957). Technical change and the aggregate production function. The Review of Economics and Statistics, 39(3), 312-320. Retrieved from http://www.jstor.org/stable/1926047

The World Bank Group. (2021). World Bank Indicators Data Repository. Retrieved 2021-10-31, from https://data . worldbank.org/indicator publisher: The World Bank Group.

UNESCO Institute for Statistics (UIS). (2020). Global Investments in R\&D (Tech. Rep. No. FS/2020/SCI/59). Retrieved from http://uis.unesco.org/

UNESCO UIS. (n.d.). Retrieved 2021-10-31, from http://uis . unesco.org/

United Nations Conference on Trade and Development. (2006). Globalization of R\&D and Developing Countries (Tech. Rep. No. UNCTAD/ITE/IIA/2005/6). Geneva: United Nations Conference on Trade and Development.

World Intellectual Property Office . (2021). WIPO Global Brand Database. Retrieved 2021-10-31, from https : //www3 . wipo . int/branddb/en/

Xuan Nguyen. (2020). Intellectual property violation in Thailand and the Philippines thriving during Covid-19. Retrieved 202110-31, from https://intellectual-property-helpdesk.ec.europa.eu/news-events/news/intellectual -property-violation-thailand-and-philippines-thriving-during-covid-19_en publisher: European Commission.

Yasuda, F., \& Kato, H. (2007). Impact of the Intellectual Property System on Economic Growth (Tech. Rep.). World Intellectual Property Organization.

How to cite this article: E. A. Onsay, (2021), Unraveling the Nexus of Science Technology Input and Economic Growth through Research Development (RD) Indicators in Asia-pacific Region: A Panel Data and Causality Analysis, Vol. 1 No. 3

This work is licensed under a Creative Commons Attribution-NonCommercial-NoDerivatives 4.0 International License 